\title{
Kronik Plak Tip Psoriasiste TNF- $\alpha$, IL-6 ve Resistin Seviyeleri
}

\section{Serum TNF- $\alpha$, IL-6 and Resistin Levels in Chronic Plaque Psoriasis}

\section{Yasemin Yıldırım, Mualla Polat, Erdinç Serin*, Ali Haydar Parlak}

Abant İzzet Baysal Üniversitesi, Tıp Fakültesi, Deri ve Zührevi Hastalıklar Anabilim Dalı, *Biyokimya Anabilim Dalı, Bolu, Türkiye

\section{Özet}

Amaç: Psoriasis kronik, tekrarlayıcı, inflamatuvar bir deri hastalığıdır. Etyolojisi ve patogenezi günümüzde tam olarak aydınlatılamamıștır. Obezite psoriasis için önemli bir risk faktörüdür ve vücut kitle indeksi hastalık șiddetiyle korelasyon gösterir. Son yıllarda psoriasisin adipoz doku sitokinleri ile iliskisi bildirilmiștir. Bu nedenle biz de bu çalısmada psoriasisli hastalarda, adipoz doku sitokinleri olan TNF- $\alpha$, IL-6 ve resistin gibi adipokinlerin düzeylerini belirlemeyi ve hastalık șiddetiyle ilișkisini değerlendirmeyi amaçladık.

Gereç ve Yöntem: Çalıșmamız Ocak-Șubat 2010 tarihleri arasında Dermatoloji polikliniğine bașvuran 40 psoriasis hastasını kapsamaktadır. Bu hastalar ile birlikte yaș, cinsiyet, vücut kitle indeksi istatistiksel fark olușturmayan 40 sağlıklı birey de kontrol grubu olarak değerlendirilmiștir. Psoriasis tanısı konulan hastalarda ve kontrol grubunda TNF- $\alpha$, IL-6 ve resistin seviyeleri ELISA yöntemi kullanılarak ölçüldü. Gruplar arası farkın değerlendirilmesi t testi ve Mann-Whitney U testi kullanılarak yapıldı. Bulgular: Hasta grubunun serum TNF- $\alpha$, IL-6, resistin seviyeleri kontrol grubuyla karșilaștırıldığında TNF- $\alpha$, IL-6 ve resistin seviyeleri hasta grubunda istatistiksel olarak anlamlı derecede yüksek saptandı. Psoriasis alan șiddet indeksi (PAȘi) skoru ile IL-6, resistin arasında istatistiksel anlamlılık tespit edildi. Hastaların TNF- $\alpha$, IL-6 ve resistin seviyeleriyle vücut kitle indeksleri arasında istatistiksel anlamlılık olmadığı görüldü. Sonuç: Bulgularımız TNF- $\alpha$, IL- 6 ve resistin'in psoriasis etyopatogenezinde rol aldığını, IL-6 ve resistin'in hastalık șiddeti ile ilgili belirteçler olabileceğini düșündürmektedir. Ayrıca çalıșmamız söz konusu sitokinlerin psorisis hastalarında adipoz doku artıșından bağımsız olarak yüksek olduğu görüșünü de desteklemektedir. Bununla birlikte konunun daha geniș çalıșmalarla desteklenmesi gerekmektedir. (Türkderm 2012; 46: 138-42)

Anahtar Kelimeler: Psoriasis, TNF- $\alpha$, IL-6, resistin

\section{Summary}

Background and Design: Psoriasis is a chronic recurrent inflammatory disease of the skin. Despite previous extensive studies, etiology is still unclear. Obesity is a significant risk factor for psoriasis and body mass index (BMI) correlates with the disease severity. In recent years, the relationship between psoriasis and adipose tissue cytokines has been reported. Therefore, in this study, we aimed to determine the levels of adipose tissue cytokines TNF- $\alpha$, IL- 6 and resistin in psoriasis patients and to evaluate their relation with disease severity.

Material and Methods: Our study was performed between January 2010 and February 2010 on a total of 40 patients who were admitted to Abant Izzet Baysal University, Medical School Clinic of Dermatology with complaints of psoriasis. Additionally, forty healthy individuals whose age, gender and BMI did not differ from the patients' ones formed the control group. TNF- $\alpha$, IL- 6 , and resistin levels were measured in both the patients diagnosed with psoriasis and the control group using ELISA methods. The ttest and Mann-Whitney $\mathrm{U}$ test were performed to examine the differences between the two groups.

Results: In our study, TNF- $\alpha$, IL- 6 , and resistin levels were all significantly elevated in the patient group, and serum IL- 6 and resistin correlated with disease severity. Psoriasis Area Severity Index (PASI) score showed statistically significant association with IL-6 and resistin levels. Furthermore, it was detected that BMI did not correlate with serum TNF- $\alpha$, IL-6, and resistin levels.

Conclusion: The results of our study showed that TNF- $\alpha, \mathrm{IL}-6$, and resistin play a part in psoriasis etiopathogenesis, and IL- 6 and resistin can be used as markers to assess the severity of the disease. Also, our study showed that the elevation in serum TNF- $\alpha$, IL- 6 , and resistin levels is independent from the increase in adipose tissue. Larger studies are needed to support our findings. (Turkderm 2012; 46: 138-42) Key Words: Psoriasis, TNF- $\alpha$, IL-6, resistin

Yazıșma Adresi/Address for Correspondence: Dr. Mualla Polat, Abant lzzet Baysal Üniversitesi, Tip Fakültesi, Deri ve Zührevi Hastallklar Anabilim Dalı, Bolu, Türkive Tel.: +90 37425346 56-3366 E-posta: polatmualla@gmail.com Geliș Tarihi/Received: 19.07.201 1 Kabul Tarihi/Accepted: 23.09.201 1 


\section{Giriş}

Psoriasis, etyopatogenezi tam olarak açıklanamamış kronik, inflamatuvar bir hastalıktır. Psoriasis genetik yatkınlığı olan bireylerde, uygun tetikleyici faktörlerin araya girmesi sonucu immün sistemin aktivasyonu, inflamasyonu sınırlayan mekanizmaların bozukluğu ve keratinositlerin hiperreaktivitesi ile ortaya çıkmaktadır .

Adipoz doku; olgun adiposit, preadiposit, vasküler, nöral ve immun hücrelerden oluşan metabolik olarak aktif bir dokudur. Adipoz dokunun, leptin, adiponektin, resistin, visfatin gibi adipokin olarak adlandırılan metabolik açıdan önemli proteinleri, tümör nekrozis faktör - alfa (TNF- $\alpha$ ), interleukin (IL)-6, monosit kemoatraktan protein1 gibi sitokin ve kemokinleri, inflamatuvar belirteçleri (fibrinojen, $C$ reaktif protein), kompleman sistem elemanlarını (C3, faktör B, faktör D), renin-anjiotensin sistem elemanlarını (anjiotensinojen ve anjiotensin II) ve güçlü bir fibrinoliz inhibitörü olan plasminojen aktivatör inhibitör1 salgılayarak vücut metabolizmasını düzenleyen aktif bir organ olduğu bilinmektedir22. Resistinin çeşitli inflamatuvar hastalıklardaki rolüyle ilgili artan çalışmalar dikkati çekmektedir. Fakat inflamasyondaki rolü fazla bilinmemektedir. Silswal ve arkadaşları insan ve kemirgen makrofajlarının insan resistiniyle inkübasyonu sonrası proinflamatuvar sitokinlerden TNF- $\alpha$, IL-12 üretiminin arttığını gözlemlemişlerdir ${ }^{3}$. Resistin ayrıca sitoplazmik kalsiyum konsantrasyonunun artışına ve fosfolipaz C aktivasyonuna neden olmaktadır ${ }^{4}$. Filkova ve arkadaşları resistinin in vitro şartlarda beyaz yağ dokusundan proinflamatuvar sitokinlerden IL-6, IL-8 ve TNF- $\alpha$ ekspresyonunu artırdığını göstermişlerdir 5 . Bu bilgiler ışığında resistinin proinflamatuvar sitokinlerle beraber inflamasyon ve immünitenin regülasyonunda önemli rolü olduğunu ve çeşitli hastalıkların patogenizinde etkin rol aldığını söyleyebiliriz

Yukarıdaki bilgiler ışığında, planladığımız bu çalışmada, inflamatuvar süreçlerde rol alan ve birbirleriyle ilişkili olan adipoz doku sitokinlerinden TNF- $\alpha$, IL-6 ve resistinin psoriasis hastalarındaki serum düzeylerini araştırdık. Araştırmamızda, aralarında yaş, cinsiyet, vücut kitle indeksi açısından istatistiksel olarak fark göstermeyen 40 sağlıklı kişiyi kontrol grubu olarak değerlendirdik ve sonuçları hasta grubumuzda elde etiğimiz sonuçlarla karşılaştırdık. Böylece sözü edilen sitokinlerin hastalık şiddetiyle ve adipoz doku kitlesi ile ilişkisini tespit etmeyi amaçladık.

\section{Gereç ve Yöntem}

Çalışma Klinik ve Laboratuvar Araştırmaları Etik Kurul Alt Kurulu'nun 2009/32 sayılı onayı alınarak Ocak 2010-Şubat 2010 tarihleri arasında Dermatoloji polikliniğine başvuran 40 psoriasis hastası ve 40 sağlıklı bireyden oluşan kontrol grubu ile yapıldı. Hastalara psoriasis tanısı dermatolojik ve histopatolojik değerlendirme ile konuldu. Çalışma dışı bırakma kriterleri; on sekiz yaşından küçük olmak, kronik plak psoriasis dışında kalan psoriasis tiplerinin varlığı, psoriasis nedeniyle son üç ay içinde sistemik veya son bir ay içinde topikal herhangi bir tedavi almak, hipertansiyon, aterosklerotik kalp hastalığı, tip 1 ve 2 diyabet, kronik böbrek ve karaciğer hastalığı, kronik obstruktif akciğer hastalı̆̆ı, nörolojik hastalık, beslenme bozukluğu, otoimmün hastalık, tiroid hastalıkları, immünsüpresif hastalık hikayesi olmak ve sistemik tedavi almak, başvurduğu anda tanımlanabilen bir infeksiyon odağı varlığı olarak belirlendi. Kontrol grubu ise kendisinde ve ailesinde psoriasis bulunmayan ve sistemik hastalık öyküsü olmayan, yaş, cinsiyet ve vücut kitle indeksi çalışma grubu ile uyumlu sağlıklı 40 bireyden oluşturuldu.

Hastaların sistemik ve dermatolojik muayeneleri yapıldı. Bel çevresi, boy ve kiloları ölçüldü. Vücut kitle indeksi $(V K i)=$ kilo $(\mathrm{kg}) /$ boy $(\mathrm{cm})^{2}$ formülü kullanılarak hesaplandı. Hastalığın şiddetini değerlendirmek amacıyla psoriasis alan şiddet indeksi (PAşi) kullanıldı. Çalışma ve kontrol grubunda yer alan kişilerden en az sekiz saatlik açlık sonrası periferik venöz kan örnekleri alındı. Kan örnekleri oda ısısında 30 dakika bekletildikten sonra 4000 devirde 15 dakika santrifüj edilip serumları ayrıldı. Serum örnekleri analiz yapılacak güne kadar $-70^{\circ} \mathrm{C}$ de saklandı. Analizden hemen önce dondurulmuş örnekler çözüldü ve A.I.B.Ü. Tıp Fakültesi Biyokimya laboratuvarında çalışıldı.

Serum TNF- $\alpha$ düzeyi Human TNF- $\alpha$ ELISA kiti kullanılarak ölçüldü (Katolog numarası BMS223/4TENCE, Bender MedSystems GmbH, Campus Vienna Biocenter 2, Vienna, Austrian). Test sonuçları 500, $250,125,62,5,32,25,15,6,7,8$ pg/ml standartlar kullanılarak oluşturulan kalibrasyon eğrisi ile hesaplandı. Testin ölçüm aralığı sıfır ile 500 pg/ml idi. Serum IL-6 düzeyi Human IL-6 ELISA kiti kullanılarak ölçüldü (Katolog numarası BMS213/2TENCE Bender MedSystems $\mathrm{GmbH}$, Campus Vienna Biocenter 2, Vienna, Austrian). Test sonuçları $100,50,25,62,5,12,5,6,25,3,13,1,56 \mathrm{pg} / \mathrm{ml}$ standartlar kullanılarak oluşturulan kalibrasyon eğrisi ile hesaplandı. Testin ölçüm aralığı sıfır ile 100 pg/ml idi. Serum resistin düzeyi ise Human resistin ELISA kiti kullanılarak ölçüldü (Katolog numarası RD191016100 BioVendor-Laboratorni Medicina Modrice, Czech Republic). Test sonuçları 50, 20, 10, 5, 2,1 ng/ml standartlar kullanılarak oluşturulan kalibrasyon eğrisi ile hesaplandı. Testin ölçüm aralığı sıfır ile 50 ng/ml idi. Tüm ELISA ölçümlerinde mikroplak yıkayıcı olarak Thermo Scientific Wellwash 4 MK 2 (Thermo Scientific, Massachusetts, ABD) kullanıldı. ELISA okuyucusu olarak Biorad Benchmark Plus (Bio-Rad Laboratories Inc, California, ABD) kullanıldı.

\section{İstatistiksel Değerlendirme}

Verilerin istatistiksel analizinde "SPSS (Statistical Package for Social Sciences) for Windows 16.0 paket programı kullanıldı. Normal dağıım varsayımını sağlayan değişkenlerin analizinde, iki grup arasındaki farkı saptamak için bağımsız örneklemler için t testi kullanıldı. Normal dağılımı sağlamayan değişkenler için ise iki bağımsız grup arasındaki fark non-parametrik testlerden Mann-Whitney U testi ve Kruskal Wallis testiyle karşılaştırıldı. Veriler arasındaki ilişki pearson korelasyon testi ile değerlendirildi. Tüm testlerde istatistiksel anlamlılık olarak $p<0,05$ değeri anlamlı kabul edildi

\section{Bulgular}

Hasta grubunun 20'si (\%50) erkek, 20'si (\%50) kadın; kontrol grubunun 21'i $(\% 52,5)$ erkek, 19 'u $(\% 47,5)$ kadındı. iki grup arasında cinsiyet bakımından istatistiksel olarak anlamlı fark saptanmadı $(p=0,823)$. Hasta grubunun yaşları 19-70 yıl arasında olup, ortalaması $39,95 \pm 14,09$ yıl idi. Kontrol grubunun yaşları 20-71 yıl arasında olup,

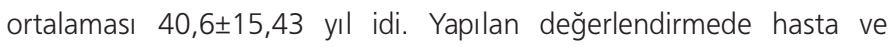
kontrol grubu arasında yaş ortalaması açısından istatistiksel olarak anlamlı fark saptanmadı $(p=0,845)$. Hasta grubunun VKi'i 17,50 ile 36,10 arasında olup ortalaması $26,63 \pm 4,98$ olarak tespit edildi. Kontrol 
Tablo 1. Hasta ve kontrol grubunun cinsiyet, yaş ve VKi ortalamaları ve $p$ değerleri

\begin{tabular}{|l|c|c|c|c|c|c|c|}
\hline & $\begin{array}{c}\text { Sayı } \\
\text { (n) }\end{array}$ & $\begin{array}{c}\text { Yüzde } \\
\text { (\%) }\end{array}$ & $\begin{array}{c}\text { Yaş ort. } \pm \\
\text { Standart sapma }\end{array}$ & $\begin{array}{c}\text { VKi } \pm \text { Standart } \\
\text { sapma }\end{array}$ & $\begin{array}{c}\text { p değeri } \\
\text { (cinsiyet) }\end{array}$ & $\begin{array}{c}\text { p değeri } \\
\text { (yaş) }\end{array}$ & $\begin{array}{c}\text { p değeri } \\
\text { (VKi) }\end{array}$ \\
\hline Hasta & 40 & & $39,95 \pm 14,09$ & $26,63 \pm 4,98$ & & \\
Erkek & 20 & 50 & $43,35 \pm 14,02$ & & 0,823 & 0,845 \\
Kadın & 20 & 50 & $36,55 \pm 13,66$ & & & \\
\hline Kontrol & 40 & & $40,60 \pm 15,43$ & $26,38 \pm 3,87$ & & \\
Erkek & 21 & 52,5 & $47,89 \pm 14,59$ & & & \\
Kadın & 19 & 47,5 & $34,64 \pm 13,67$ & & & \\
\hline
\end{tabular}

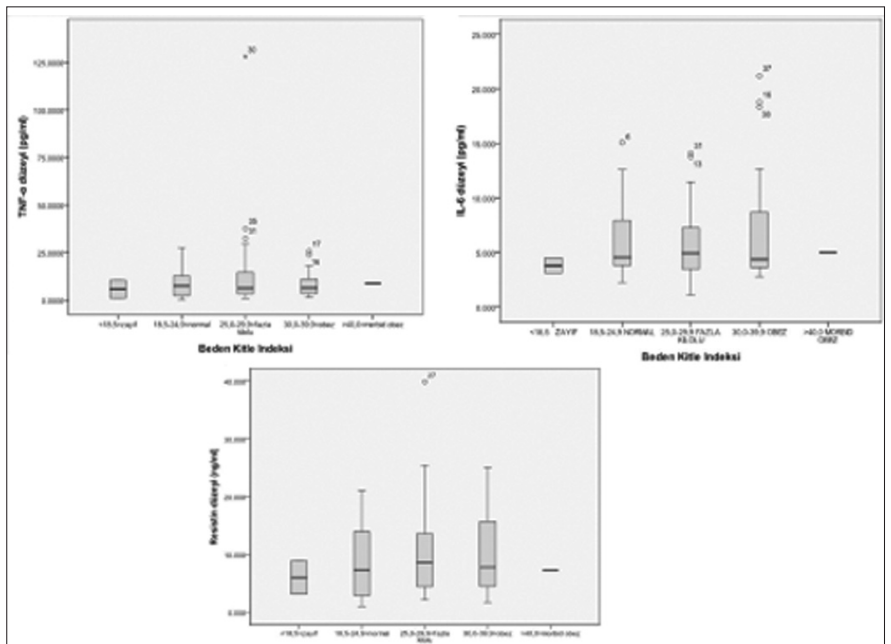

Şekil 1. PAŞi ile TNF- $\alpha$, IL-6 ve Resistin düzeylerinin karşılaştırılması

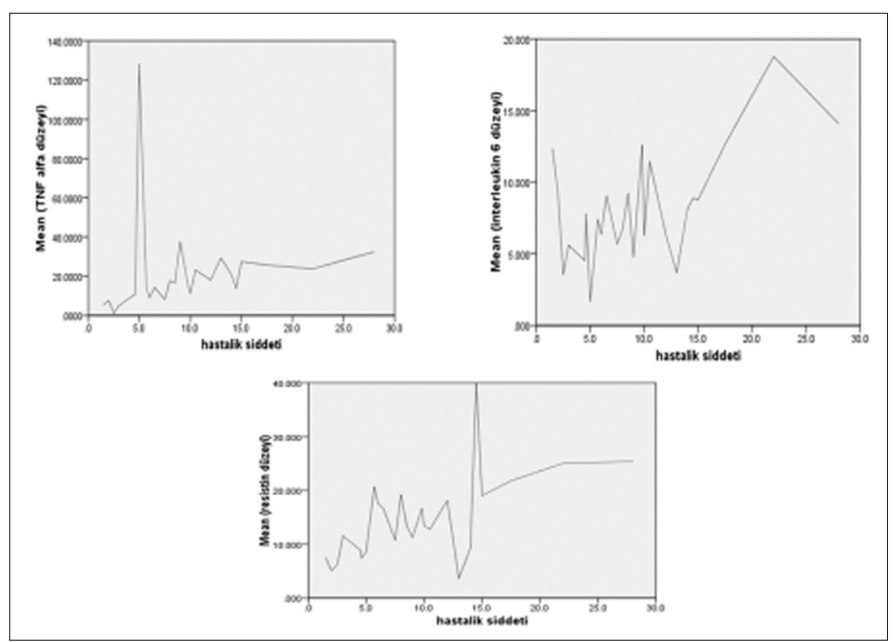

Şekil 2. VKi ile TNF- $\alpha$, IL-6 ve Resistin düzeylerinin karşılaştırılması

grubunun VKi 18,60 ile 49,40 arasında olup, ortalaması 26,38 $\pm 3,87$ olarak tespit edildi. Hasta ve kontrol grubu arasında VKI açısından istatistiksel olarak anlamlı fark bulunmadı ( $p=0,826)$, (Tablo 1).

Hastaların PAşi değerleri 1,5 ile 28 arasında değişmekteydi. PAŞi değerlerinin ortancası 6,5 , ortalaması $8,5 \pm 5,72$ olarak tespit edildi. Hasta grubunun TNF- $\alpha$ değerleri 1,08 pg/ml ile 12,07 pg/ml arasında olup ortalaması $17,11 \pm 20,04 \mathrm{pg} / \mathrm{ml}$ olarak tespit edildi. Kontrol grubunun TNF- $\alpha$ değerleri $0,13 \mathrm{pg} / \mathrm{ml}$ ile $11,10 \mathrm{pg} / \mathrm{ml}$ arasında olup ortalaması $4,19 \pm 2,98 \mathrm{pg} / \mathrm{ml}$ olarak tespit edildi. Hasta grubunda TNF- $\alpha$ değerleri kontrol grubuna göre istatistiksel olarak anlamlı
Tablo 2. Hasta ve kontrol grubunun PAŞi, TNF- $\alpha$, IL-6, Resistin değerleri

\begin{tabular}{|c|c|c|c|c|}
\hline & & n & $\begin{array}{c}\text { Ortalama } \pm \text { Standart } \\
\text { sapma }\end{array}$ & p değeri \\
\hline PAŞI & $\begin{array}{l}\text { Vaka } \\
\text { Kontrol }\end{array}$ & $\begin{array}{l}40 \\
40\end{array}$ & $8,5 \pm 5,72$ & \\
\hline TNF- $\alpha(p g / m l)$ & $\begin{array}{l}\text { Vaka } \\
\text { Kontrol }\end{array}$ & $\begin{array}{l}40 \\
40\end{array}$ & $\begin{array}{c}17,11 \pm 20,04 \\
4,19 \pm 2,98\end{array}$ & 0,001 \\
\hline IL-6 (pg/ml) & $\begin{array}{l}\text { Vaka } \\
\text { Kontrol }\end{array}$ & $\begin{array}{l}40 \\
40\end{array}$ & $\begin{array}{l}8,15 \pm 4,56 \\
3,99 \pm 1,64\end{array}$ & 0,001 \\
\hline Resistin (ng/ml) & $\begin{array}{l}\text { Vaka } \\
\text { Kontrol }\end{array}$ & $\begin{array}{l}40 \\
40\end{array}$ & $\begin{array}{l}13,84 \pm 7,66 \\
5,76 \pm 4,49\end{array}$ & 0,001 \\
\hline
\end{tabular}

derecede yüksek bulundu ( $p=0,001)$ (Tablo 2). Hasta grubunda PAŞi yükseldikçe TNF- $\alpha$ değerindeki artış istatistiksel olarak anlamlı bulunmadı $(p=0,137)$ (Şekil 1).

Hasta grubunun IL-6 değerleri 1,67 pg/ml ile 21,19 pg/ml arasında olup ortalaması $8,15 \pm 4,56 \mathrm{pg} / \mathrm{ml}$ olarak tespit edildi. Kontrol grubunun IL-6

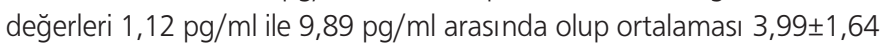
$\mathrm{pg} / \mathrm{ml}$ olarak tespit edildi. Hasta grubunda IL-6 değerleri kontrol grubuna göre istatistiksel olarak anlamlı derecede yüksek bulundu $(p=0,001)$ (Tablo 2). Hasta grubunda PAşi yükseldikçe IL-6 değerindeki artış istatistiksel olarak anlamlı bulundu $(p=0,045)$ (Şekil 1).

Hasta grubunun resistin değerleri $3,02 \mathrm{ng} / \mathrm{ml}$ ile $39,900 \mathrm{pg} / \mathrm{ml}$ arasında olup ortalaması $13,84 \pm 7,66 \mathrm{ng} / \mathrm{ml}$ olarak tespit edildi. Kontrol grubunun resistin değerleri $1,01 \mathrm{pg} / \mathrm{ml}$ ile $22,12 \mathrm{ng} / \mathrm{ml}$ arasında olup ortalaması 5,76 $\pm 4,49 \mathrm{ng} / \mathrm{ml}$ olarak tespit edildi. Hasta grubunda resistin değerleri kontrol grubuna göre istatistiksel olarak anlamlı derecede yüksek bulundu $(p=0,001)$ (Tablo 2). Hasta grubunda PAŞi yükseldikçe resistin değerindeki artış istatistiksel olarak anlamlı bulundu ( $p=0,001)$ (Şekil 1).

Hasta grubunda TNF- $\alpha$ ile resistin değerleri, TNF- $\alpha$ ile IL- 6 değerleri ve resistin ile IL-6 arasında aynı yönlü istatistiksel olarak anlamlı ilişki saptandı ( $p=0,001, p=0,001, p=0,001$ ). Hasta grubunda TNF- $\alpha$, IL-6 ve resistin düzeyleri ile VKi arasında istatistiksel olarak anlamlı ilişki saptanmadı ( $p=0,91, p=0,87, p=0,61$ ) (Şekil 2 ).

\section{Tartışma}

TNF- $\alpha$ çeşitli inflamatuvar, infeksiyöz ve malin durumların patogenezinde önemli rolü olan proinflamatuvar bir sitokindir7. TNF$\alpha^{\prime}$ nın, psoriasisli hastaların serumunda ve psoriatik deride yüksek miktarda bulunması, düzeyinin etkili tedavi sonrası serum ve lezyonel deride azaldığının gösterilmesi, TNF- $\alpha$ antagonistlerinin (etanercept, 
infliksimab, adalimumab) psoriasis tedavisinde etkili olması, TNF- $\alpha$ 'nın psoriasis patogenezindeki önemini desteklemektedir6,8-10. Lezyonel deri veya serumdaki TNF- $\alpha$ konsantrasyonlarının PAŞi skoru ile doğrusal ilişkisini gösteren yayınlar da bu hipotezle uyumludur8,9. Arıcan ve arkadaşları psoriasisli hastalarda hastalık şiddetini belirlemede PAŞi değeri yerine kullanılabilecek basit bir laboratuvar tetkiki bulmak amacıyla psoriasis patogenezinde rol alan çeşitli sitokinlerin seviyesini ve bu sitokinlerin hastalık şiddetiyle olan ilişkisini araştırmışlardır. Serum TNF- $\alpha$ seviyelerini psoriasis hastalarında yüksek bulmuş, fakat TNF- $\alpha$ seviyeleri ile hastalık şiddeti arasında anlamlı ilişki saptamamışlardır11. Bununla birlikte, Mussi ve arkadaşları çalışmalarında TNF- $\alpha$ seviyelerini kontrol grubuna göre belirgin olarak yüksek bulmuş, TNF- $\alpha$ seviyeleri ile PAŞi değerleri arasında anlamlı ilişki saptamış ve etkili tedavi sonrası hem PAşi skorlarının hem de TNF- $\alpha$ seviyesinin anlamlı derecede azaldığını, TNF- $\alpha$ 'nın hastalık şiddetini göstermede kullanılabilecek bir belirteç olduğunu belirtmişlerdir ${ }^{12}$. Hastalık şiddeti ve tedavi sonrasında TNF$\alpha$ seviyesindeki değişim birçok çalışmayla da desteklenmiştir13-16.

Bizim çalışmamızda ise, psoriasis hastalarında TNF- $\alpha$ değerleri kontrol grubuna göre istatistiksel olarak anlamlı derecede yüksek bulunmuştur $(p<0,05)$. Ancak araştırmamızda psoriasis hastalarında PAşi değerleri ile TNF- $\alpha$ seviyeleri arasında istatistiksel olarak anlamlı bir ilişki saptanamamıştır $(p=0,137)$. Diğer taraftan psoriasis hastalarında serum TNF- $\alpha$ seviyesi ile VKi arasında istatistiksel olarak anlamlı ilişki belirlenememiştir $(p=0,906)$. Sonuç olarak, yaptığımız çalışmanın bulguları, diğer çalışmalar gibi TNF- $\alpha$ 'nın psoriasisteki inflamatuvar süreçte yer aldığını desteklemektedir. Bununla beraber, birçok çalışmada savunulduğu gibi TNF- $\alpha$ 'nın hastalık şiddetinin bir göstergesi olduğuna dair bir sonuca ulaşımamıştır. Bu konuda literatürde de çelişkili sonuçlar dikkat çekmektedir. Ayrıca VKi ile TNF- $\alpha$ seviyesi arasında istatistiksel olarak anlamlı ilişkinin olmaması TNF- $\alpha$ salınımının adipoz dokudan bağımsız olarak yüksek olduğunu göstermektedir.

Bilindiği üzere IL-6 proinflamatuvar sitokinlerden biridir ve dolaşımdaki miktarının yaklaşık üçte biri yağ dokusu kaynaklıdır17. IL-6'nın psoriasiste görülen kronik inflamasyonda ve keratinosit proliferasyonunda etkili olduğu bilinmektedir6. Zalewska ve arkadaşları serumda IL-6 düzeyini psoriasis hastalarında kontrol grubuna göre anlamlı derecede yüksek bulmuşlar ve tedavi sonrası IL6 seviyesinin düştüğünü gözlemlemişlerdir. Fibroblast kültürlerinde ise IL-6 düzeyinin farklı olmadığını göstermişlerdir18. Sonuç olarak serum IL-6 düzeyinin psoriasis aktivitesini ve tedaviye yanıtı gösteren bir belirteç olabileceğini ve IL-6 düzeyinin fibroblast kültürlerinde yükselmemiş olmasını ise psoriasiste artmış IL-6'nın ana kaynağının fibroblastlar olmadığını belirterek açıklamışlardır18. IL-6'nın psoriasis patogenezinde önemli rolünün olması yanında hastalığın şiddetini ve tedaviye olan yanıtı değerlendirmede kullanılabilecek objektif bir gösterge olabileceği de savunulmaktadır13-16,19-21.

Bizim çalışmamızın bulgusu da yukarıdaki değerlendirmeye paraleldir. Araştırmamız IL-6'nın psoriasisteki inflamatuvar süreçte yer aldığını ve serum IL-6 düzeyinin hastalık şiddetini değerlendirmekte kullanılabilecek bir belirteç olabileceğini desteklemektedir. Ancak VKi ile IL-6 arasında anlamlı bir ilişkinin tespit edilememiş olması, adipoz doku artmadan da IL6 salgılanmasında artış olduğunu yani hastalığın mevcut adipoz doku kitlesinin varlığından bağımsız olarak şiddetlenebileceğini göstermektedir. Resistin, proinflamatuvar özellikte bir adipokindir ve son zamanlarda psoriasis gibi çeşitli inflamatuvar hastalıklardaki rolüyle ilgili çalışmalar dikkati çekmektedir22. Bu konudaki araştırmalardan birinde Johnston ve arkadaşları psoriasisle obezite, serum leptin ve resistin seviyeleri arasındaki ilişkiyi araştırmışlar ve psoriasisli hastalarda serum resistin düzeyi kontrol grubuna göre yüksek bulunmuştur. Ayrıca hastalık şiddetiyle resistin seviyesinin pozitif korrelasyon gösterdiği bildirilmiştir ${ }^{9}$. Johnston ve arkadaşları ayrıca resistinin ex vivo ortamda kan monositlerinden CXCL8 ve TNF- $\alpha$ üretimini anlamlı derecede arttırdığını gözlemlemişlerdir ${ }^{9}$. Boehncke ve arkadaşlarının yaptıkları çalışmada ise serum resistin seviyesindeki artışla hastalık şiddetinin arttığı bildirilmiştir23.

Biz de yukarıda sözü edilen bulgulara paralel olarak çalışmamızda serum resistin düzeylerini sağlıkı kontrol grubuna göre istatistiksel olarak anlamlı derecede yüksek bulduk $(p<0,05)$. Ayrıca hastalık şiddetinin artmasıyla istatistiksel olarak anlamlı derecede resistin seviyesinin yükseldiğini gözledik $(p<0,05)$. Psoriasis hastalarında VKi ile serum resistin seviyesi arasında istatistiksel olarak anlamlı ilişki saptamadık $(p=0,610)$. Bu sonuçlar resistinin psoriasisteki inflamatuvar süreçte yer aldığını ve serum resistin düzeyinin hastalık şiddetini değerlendiren bir belirteç olabileceğini desteklemektedir. Sonuç olarak; çalışmamızda sonuçların etkilenmemesi için yaş, cinsiyet gibi faktörlerin yanısıra özellikle adipoz dokudan salgılandığı bilinen sitokinlerin düzeylerinin etkilenmemesi için VKI açısından da standardize edilmiş gruplar arasında çalışı ldığında dahi TNF- $\alpha$, IL-6 ve resistinin hasta grubunda yükseldiğini tespit ettik. Bu bulgular hastaların kilolarından bağımsız olarak TNF- $\alpha$, IL-6 ve resistinin yüksek olduğunu ayrıca PAŞi arttıkça IL-6 ve resistinde artış olması bu sitokinlerin adipoz doku dışından da hastalık aktivasyonunu etkileyecek düzeyde yüksek olarak salgılandığını göstermektedir. Salgılanan sitokinlerin adipoz doku kaynaklı olup olmadığını göstermekte VKi tek parametre olmayacağı için verilerimizin daha geniş hasta gruplarında, kontrollü çalışmalarla, doku düzeyinde sitokin ölçümü yapılarak desteklenmesi gerektiğini düşünüyoruz.

\section{Kaynaklar}

1. Van de Kerkhof PCM: Psoriasis. Dermatology. Ed. Bolognia JL, Jorizzo JL, Rapini RP. London, Mosby, 2003;125-49.

2. Juge-Aubry $C E$, Henrichot $E$, Meier $C A$ : Adipose tissue: a regulator of inflammation, Best Pract Res Clin Endocrinol Metab 2005;19:547-66.

3. Silswal $N$, Singh $A$, Aruna $B$, et al: Human resistin stimulates the proinflammatory cytokines TNF-alpha and IL-12 in macrophages by NF kappa B dependent pathway. Biochem Biophys Res Commun 2005;334:1092-101.

4. Aruna B, Ghosh S, Singh A.K, et al: Human recombinant resistin protein displays a tendency to aggregate by forming intermolecular disulfide linkages. Biochemistry 2003;42:10554-59.

5. Filkova M, Haluzik M, Gay S, Senolt L: The role of resistin as a regulator of inflamation: implication for various human pathologies. Clin Immunol 2009;133:157-70.

6. Nickoloff BJ, Xin H, Nestle FO, Qin JZ: The cytokine and chemokine network in psoriasis. Clin Dermatol 2007;25:568-73.

7. JR Bradley: TNF mediated inflammatory disease. J Pathol 2008;214:149-60.

8. Bonifati C, Carducci M, Cordiali-Fei P, et al: Correlated increases of tumor necrosis factor-alpha, interleukin-6 and granulocyte monocyte colony stimulating factor levels in suction blister fluids and sera of psoriatic patients: relationships with disease severity. Clin Exp Dermatol 1994:19:383-87.

9. Johnston A, Arnadottir S, Gudjonsson JE, et al: Obesity in psoriasis: leptin and resistin as mediators of cutaneus inflammation. $\mathrm{Br}$ J Dermatol 2008; 159:342-50.

10. Berköz M, Yalın S: Immunologic and inflammatory functions of adipose tissue. Mersin Univ Saglık Bilim Derg 2008;1:1-9. 
11. Arican $O$, Aral M, Sasmaz $S$, Ciragil P. Serum levels of TNF-alpha, IFN gamma, IL-6, IL-8, IL-12, IL-17 and IL-18 in ptients with active psoriasis and correlation with disease severity. Mediators In flamm 2005;2005:273-79.

12. Mussi A, Bonifati C, Carducci M, et al: Serum TNF-alpha levels correlate with disease severity and are reduced by effective therapy in plaque-type psoriasis. J Biol Regul Homeost Agents 1997;11:115-8.

13. Abanmi A, Al Harthi F, Al Agla R, et al: Serum levels of proinflammatory cytokines in psoriasis patients from Saudi Arabia. Int J Dermatol 2005:44:82-3.

14. Gönül T, Başak PY, Kara $Y$, et al: Psoriasisli hastalarda serum leptin düzeylerinin araştırılması. Turkderm 2009;43:48-52.

15. Chodorowska G: Plasma concentrations of IFN- gama and TNF-alpha in psoriatic patients before and after local treatment with dithranol ointment. J Eur Acad Dermatol Venerol 1998;10:147-51.

16. Takahashi H, Tsuji H, Hashimato $Y$, et al: Serum cytokines and growth factor levels in Japanese patients with psoriasis. Clin Exp Dermato 2010;35:645-9
17. Fried SK, Bunkin DA, Greenberg AS: Omental and subcutaneous adipose tissues of obese subjects release interleukin-6: Depot difference and regulation by glucocorticoid. J Clin Endocrinol Metab 1998;83:847-50.

18. Zalewska A, Glowacka E, Wyczolkowska J, et al: Interleukin 6 and 8 levels in plasma and fibroblast cultures in psoriasis. Mediators Inflamm 2006;1:1-6.

19. Sagawa Y, Shiohara T, Imanishi K, Nagashima M: Is sustained production of tumor necrosis factor-alpha relevant to the development of pustular psoriasis? Dermatol 1993;187:81-3.

20. Szepietowski JC, Bielicka E, Nockowski P, et al: Increased interleukin-7 levels in the sera of psoriatic patients: lack of correlations with interleukin6 levels and disease intensity. Clin Exp Dermatol 2000;25:643-7.

21. Deeva I, Mariani S, De Luca C, et al: Wide-spectrum profile of inflammatory mediators in the plasma and scales of patients with psoriatic disease. Cytokine 2010;49:163-70.

22. Bokarewa M, Nagaev I, Dahlberg L, et al: Resistin, an adipokine with potent proinflammatory properties. J Immunol 2005;174:5789-95.

23. Boehncke $S$, Thaci $D$, Beschmann $H$, et al: Psoriasis patients show signs of insulin resistance. Br J Dermatol 2007;157:1249-51. 